\title{
Snorri Sturluson in Italy: An Interview With Dario Giansanti and Stefano Mazza
}

\author{
by Dario Giansanti e Stefano Mazza
}

\section{Introductory note}

Dario Giansanti and Stefano Mazza are two amateur scholars who, in their spare time, have been developing The Bifröst Project (BP; www.bifrost.it), an Italian web resource dedicated to ancient and early-medieval languages, mythologies and cultures. BP is an entirely open-access project, to whom anyone can contribute. The person chiefly responsible for the project is Dario Giansanti, who has been running the website since 2004. Concerning its Nordic section, BP is now working on the Italian translation of several medieval Scandinavian texts, thus aiming at becoming a highly valuable resource for both concerned readers and qualified scholars. One of the most recent and demanding endeavours that BP has accomplished to date is a brand new edition of the Snorra Edda for the Italian public, which is available at the following URLs:

- Preface

- $\quad$ Fyrirsögn ok Formáli

- Gylfaginning

- Skáldskaparmál

- $\quad$ Gróttasöngr (part of Skáldskaparmál)

The work is still in progress and it is regularly updated. The BP blog, called Gangleri, is also available to this end: gylfaginning.wordpress.com.

Legenda:

NM: Nordicum-Mediterraneum

DG: Dario Giansanti.

SM: Stefano Mazza.

NM: Dario, let us talk about BP. When and how was the original idea developed?

DG: BP was born officially in January 2004, when I displayed the first website setup. On my own part, I've always been a voracious reader of myths, legends, epic poems and chansons de geste. I created the website to share my passion with other people, offering a place to find stories taken from sources too often unaccessible or very difficult to locate. I also felt that in Italy we have never had any site concerning mythology that could be really exhaustive and complete, so I decided to open to the 
public the research work that I was keeping in my personal archives. Since then, BP has always been an open-access workshop, to whom anyone can contribute. Soon after the opening of $\mathrm{BP}$, other enthusiasts have joined the project, giving life to a small but very solid team, whose members share the common aim to create a free and highly valuable resource for literature, mythology, anthropology and any other intriguing aspect of cultures of the past. One of BP's main tasks is the collection and translation of literary texts, with a strictly scientific and philological attitude. After five years of activity, the project has collected a number of materials and original translations: the Gaelic Book of Taking of Ireland, the Old Russian Song of Igor's Campaign, the Finnish Kalevala, some poems from the Poetic Edda, ancient Irish poems, ballads from medieval Scandinavia, Old High German poems, etc. plus a corpus of studies and essays covering a wide range of arguments and cultural areas. An area still being developed concerns simple introductions to languages such as Sanskrit, Gaelic, Welsh, and some Semitic languages too. Finally, when Stefano joined the project in 2006, we started to work at a new translation of the Snorra Edda.

\section{NM: Who is the typical BP reader?}

DG: I wish to answer that we have become a landmark for graduates and academics, who are surely amongst our readers, but I think that the majority of our visitors are just curious people and enthusiasts of fantastic literature. Some are even heathen believers or neo-pagans in search of original texts to use as references for their beliefs. For example, I have received messages asking me to translate some sentences into "elvish tongue" and requesting information on how to build an altar for Hecates... More recently, we have also received questions from university students, who demands permission to use our texts for their graduation theses. However, the truth is that the site was born as a small place to publish some material I had collected day by day. Later, the volume and the quality of the contents have increased, mainly thanks to valid contributors that have spontaneously offered their work and aid. Now, as a unique case in the Italian internet community, we can claim to host the complete Kalevalametric translation and the Edda, together with other antiquarian works of high literary value. It's incredible, I can hardly believe it...

\section{NM: How do you select the material to be published on BP? What are your quality standards?}

DG: There are basically two ways to deal with mythology: a "narrative approach" and an "essayistic approach". The first case is when an anthology of ancient stories is assembled and one can decide to use the unabridged, original texts in their strictly philological form, or to present a more informative and somewhat reduced narration thereof. The second case is when the myth is presented through the analytical and interpretative work of a specialist, offering the conclusions of authoritative scholars, or the results of a personal piece of research. For BP we decided to allow both approaches, in order to have multiple levels of depth for each topic we cover. Whoever enters BP can just read the stories of gods and heroes to satisfy his own 
curiosity, but if he wishes to learn more, then he has also the opportunity to go deeper, reading notes, commentaries or even essays and articles that focus on specific issues.

Regarding the narrative part, our starting materials are always original texts, used in academic, scholarly research or generally recognised as valuable and reliable. Whenever possible, we avoid translations, unless they are very accurate and none of us knows the language of the source text. In any case, we never use digests or reworks. Regarding the essayistic part, our aim is to present highly accurate and original studies on mythical characters and stories, with a critical and scientific point of view.

SM: To summarize, we can say that there are three things that we ask for publication on BP: philology, objectivity and originality.

NM: BP is a multi-cultural project, for which you are collecting mythologies and legends from several countries. You are translating into Italian original materials in different languages. Where have you, Dario and Stefano, learned Old Norse and the other languages you are translating from?

SM: The language I'm now specialising in is Old Norse, which I have learned basically on my own, in my spare time, when I started this activity I already had a full-time job and I couldn't attend any regular course. Anyway, I must say that when I was at high school I attended classical Latin and Greek courses, thanks to which I've learned the basics of philology and a general method for the study of ancient languages. During high school I took also a German literature course, so I had the opportunity to study interesting poems like the Hildebrandslied, Merseburger Zaubersprüche, to learn something of the Old German dialects. When later I moved to the University I did chose a scientific degree, and in 2002 I graduated in biotechnology. Then, I followed my academic education, starting to work as a researcher in the food industry, which is my current job, but I've always kept a parallel interest for ancient languages and mythologies. My first attempts in this direction were with Old and Middle English literature: I started to study Beowulf Sir Gawain and the Green Knight, which I enjoyed very much, but later my desire was to know more of the Norse culture, about which I knew very little, so I began to search material on the Edda and on the Icelandic sagas. The problem was that the available Italian translations were (and are) very few and difficult to locate. Plus, as I expected, Italy still lacked a complete and critical edition of Snorri's Prose Edda, even if it's an absolute masterpiece of medieval Europe. At the same time, I started to develop an idea: to learn Old Norse as a hobby and to translate the Prose Edda in my spare time for myself and for those who, like me, wanted to know more about the Scandinavian culture via the original Icelandic sources. Unexpectedly, the web was full of resources for anyone who wants to learn such a language, so I followed a few on-line courses and bought some books to study. In a few months, I was able to understand simple Norse texts like the first chapters of Gylfaginning, the most renown book of the Snorra Edda, which is quite simple to read and it's even used as entry-level practice 
text. Later I felt ready to accomplish a more demanding task, like the translation of a full work.

DG: My interest in languages, especially in glottology and comparative linguistics, dates back to the early years of my university studies. A little work I did for my course in anthropology concerned the origins and the development of language. Then I deepened and improved my knowledge of Indo-European studies and the classification of languages. I didn't aim at speaking or reading any specific language; rather at knowing their structures, grammars and roots. In the following years, I was very interested in Greenberg-Ruhlen's hypothesis about mass-comparison languages (heavily criticised today), and in Cavalli-Sforza's comparison between genetic and linguistic family-trees. At the same time, I pursued personal studies in myths, legends and popular traditions. I read Dumézil, De Vries, Propp, Campbell and other authors, and I began to apply comparative methods in my studies of mythology. It was quite natural for me to step into the original texts of various literary traditions, and the languages in which they had been written. I began to study Old Norse on Scovazzi's grammar for reading the Eddasand the Sagasin the original. In 2005 I tried to translate some poems from the Poetic Edda, making use of all the critical material and translations that I could find. These translations of mine--Völuspá, Hávamál, Vafbrúđnismál, Grímnismáland Skírnismál--although imperfect and improvable, are now available on BP.

\section{NM: Amongst the cultural areas covered by BP, how important is Norse mythology?}

DG: I think that Norse mythology is actually one of the most developed and wellmanaged in BP. The Germanic area in general is possibly the richest and most constantly updated section. Besides, the Snorra Edda de factothe biggest translation to date. I must also add that a big part of our readers are specifically interested in Norse culture and many of them have praised Bifröst for its Norse mythology area. Curiously, the section that we have never opened is the one for Classic i.e. Greek and Latin mythology. This is quite odd for an Italian site, anyway that's the point: we have never been Classics- or Mediterranean-oriented; simply, we have been following the spontaneous interests of our editors and we have collected a large number of publications concerning myths and legends of Germanic, Ugro-Finnish, Celtic and Russian cultures. We hope that this will be considered as a good service for the Italian readers, who may know and learn about Classic mythology much more easily, because there is no lack of books about this subject in our country, whereas on the other side they have fewer chances to approach other ancient cultures.

NM: How did you Dario and Stefano get in touch for the translation of Edda?

SM: When I started my self-taught course of Old Norse, I already knew the BP. When I found it out the first time, I regarded it as a very promising free resource dedicated to languages, legends and mythology. Immediately, I desired to give my own contribution to this project, so at the beginning of 2006 I introduced myself to Dario 
as an amateur Old Norse translator. He answered me immediately, telling me that he wished to work on the Prose Edda for his website, sharing my willingness to obtain a definitive and complete edition. I took up this challenge at once: in spring 2006 I joined the project and in the summer the first part of the Gylfaginningwas published on BP. That time a little dream came true for me: what I had begun out of simple curiosity was now taking the shape of a serious philological project.

NM: Could you please explain why you think that a new Italian translation of the Edda was so desirable?

DG: I started to work at the Scandinavian section of BP, I felt the lack of a serious, critical edition of the Prose Edda. What we have now are two good translations of the Gylfaginningand a small part of the Skáldskaparmál, one by Giorgio Dolfini and one by Gianna Chiesa Isnardi. Both are excellent, but published for a generic public: they are incomplete (in Skáldskaparmál) and have not yet a critical apparatus annexed to them. Divulgation literature - whose merits are undoubted - has nevertheless influenced our vision of ancient and medieval mythology. It has helped me to understand what exactly Snorri said and directly compare his text with the information from the Poetic Edda, without passing through the interpretations of other scholars. Still, it was really necessary to have a good and complete edition of the Snorra Edda. My spare time was insufficient, and my skills inadequate. Luckily, Stefano offered me his contribution and his competence. His translation of Snorra $E d d a$ is very careful and precise: his work is much better than I could ever expect.

SM: In my opinion, the main reason for a new translation is that in Italy we have never had a true Snorra Edda translation. Dolfini's and Isnardi's Prose Edda versions are very good, they have been pioneering and also inspiring translations for anyone interested in medieval Scandinavia, but it's a pity that they have remained unfinished. The Gylfaginningand the related prose texts in the

Skáldskaparmálchosen for Italian public are beautiful, very intriguing epic tales, but the Edda of Snorri goes far beyond a mere antiquarian anthology, and I strongly think that it should be presented for what it is: a complex, raw, enigmatic, hardly definable and probably unfinished masterpiece of Norse literature - indeed of the European medieval canon. Many theories have been attempted by generations of scholars about the nature of this work and still we don't know what exactly Snorri Sturluson had in mind when he assembled this book, but what we know for sure is that without his Edda we wouldn't know very much about the culture of medieval Scandinavia and we would know even less of skaldic and eddaic poetry. Therefore, Dario and I really think that such a masterpiece deserves our full attention: a complete critical edition, with notes and extensive commentary, was the least that we could do in view of a serious contribution to the Italian readers. There is also a second reason for publishing a new edition that I wish to underline: none of the Italian Edda translations presents the original text. It's my opinion that, especially in the case of ancient literature, the original text is very important, and not just an extra feature for scholars or curious readers. Anyone who wishes, should be able to see and verify the choices of the translator, and this is possible only if the original text is present 
alongside the translation. It should be taken as a guarantee or a token of responsibility by the editor and the translator before their readership.

NM: What is your favourite passage in the Edda?

SM: For me it's not easy to answer, because the Prose Edda has so many "faces", as I said before, and each of them has its own point of interest. Anyway, I think that among the passages that I enjoyed most to read there are the adventures of Pórr. In these tales, Pórr acts both as a god and a hero and is always challenged by cosmic forces that assume the forms of giants, illusions or monsters. The narrative possesses something truly "magnetic" for me and the tales are full of imagination and surprising characters. Another passage that I like very much is the Song of Grótti[Gróttasöngr], one of my favourite Norse poems. It is a very complex song about an ancient story, terrible and moving at the same time.

DG: The Hermóðr's journey to Hel. It's an "hápaxmyth”, a story that appears nowhere else, and this reason renders Snorri's episode very precious for us. After Baldr's corpse is placed on the burial ship, and all hope seems lost, Hermódr jumps on Sleipnir's back and shoots off in his desperate effort. It's a touching scene. There is real emotion in it.

\section{NM: Is Snorri Sturluson popular in Italy?}

SM: No, I think he's not. Snorri and his work are known mainly by people with highly specific literary interests, especially in Icelandic or Scandinavian culture, mostly academics and amateur scholars in Medieval literature. It is quite unusual that the average educated Italian may read unprompted Snorri Sturluson. Icelandic sagas, in general, are known to Italians as a literary genre, together with remote fragments of Norse mythology, but nothing more. Just to mention a typical case, last year I spoke at a conference on Snorri and the Edda for the students of a High School in my hometown. In this kind of school there are mainly literary and humanistic courses, where one has the opportunity to learn Latin and Ancient Greek literature and mythology. However, none of the students of the school and not even their teachers knew anything about what I was telling, and not only about Snorri, the Edda and Icelandic history: many of them completely ignored even popular themes like the history of the Vikings or the names of Norse gods and heroes. This can be taken as a revealing example of how alien Snorri Sturluson can be to Italian culture.

NM: Are you currently working on other translations besides the Edda?

SM: When I began to translate the first Norse texts I didn't have a true project in mind, the only clear task I had was to learn the language. For this reason, when I started to work at the Edda I also began to translate passages from other books: for example from the Saga of Hervör and Heidrek, which I find of particular interest for its antiquity and its hybrid fashion, or even from the Old English Christof Cynewulf. However, I soon realized that it would have been better both for me and for BP to 
focus on one project only and I have then decided to use all my energies for the Prose Edda translation, leaving behind any additional side-project. Later I also discovered that inside the Prose Edda there are passages that can be treated and studied as single works: for example, last year we've published the Song of Grótti[Gróttasöngr], which is part of Snorri's Skáldskaparmál, as an independent translation, with its own commentary and notes. Since it belongs to the so-called "Minor Edda" or Eddica Minora, we also seized the opportunity to open a new section in BP, to which we have recently added Baldr's dreams[Baldsdraumar], another "minor" eddaic poem, translated by another contributor, Luca Taglianetti.

DG: We have certainly no lack of projects! Some poems from Eddica Minora (Hyndluljóð, Rígspula, Gróagaldrand Fjólsviðsmál), translated by Luca Taglianetti, are nearly ready for publication. After that, I hope to complete the Poetic Edda, and obviously to publish some skaldic poems, such Pórsdrápaor Haustlöng, both very important as mythological sources. Other projects can be a little Poetic Lexicon, a list of kenningarand heiti. And, why not, an on-line Old Norse grammar.

\section{NM: Do you have other projects besides those pertaining to Germanic mythology?}

DG: BP should host traditions from more cultural areas. The interests of our contributors as well as the interests of the public have brought about the privileged development of the section devoted to Germanic mythology and literature.

Nevertheless there are many projects that remain unfinished. For example, the medieval chansons de gestefrom the Charlemagne cycle are absolutely unknown in Italy, unlike the Arthurian cycle, which is very popular at many levels. This is a real pity. Now, with the help of the Armenian community of Rome, I hope to publish as soon as we can an Italian translation of Moses of Khorene's History of Great Armenia, a chronicle about the origins and the legendary kings of ancient Armenia (very interesting for its connections with Iranian traditions). And even about Classical mythology, I think that a serious comparative study is still missing. The truth is that we are few people, our spare time is very little, and the work to do is huge...

NM: Are there, in your opinion, many Italians interested in Iceland and its culture?

SM: Sincerely, I can't tell how many Italians are interested in Icelandic culture. It is my opinion that there are several reasons for Italians to be interested in Iceland and in the other Nordic countries, but maybe many Italians still know very little about Iceland, because they see it as a very "distant" and even "otherworldly" reality, somewhere near the Arctic Pole and thus not pertaining the "Continental" European continuum. In this sense, we still see Iceland not far from how it was depicted by Olaus Magnus in his Carta Marina of the 16th century: a perilous realm, encircled by whirlpools, always menaced by the jaws of enormous monsters and probably inhabited by uncanny creatures... Italy and Iceland are very distant countries, which have developed in different historical periods and under completely different conditions. Nevertheless, we know that in a distant time their peoples originated 
from a single cultural unity, and this far origin has left some faint, common traces in the language, mythology and literature of both countries. What I find intriguing and stimulating is also the identification of these ancient common traits, which one can find mainly in language, folklore and mythology.

DG: In my experience, there is a genuine interest in medieval literature and mythology, at many levels. But there are many prejudices too. A certain kind of popular literature and media exposure has surely contributed to spreading the knowledge of Nordic culture among the public at large, but at the same time it has provided an idea of it that is only picturesque and not very reliable.

NM: Do you think that BP can contribute to promote the Nordic culture and in particular the Icelandic culture?

SM: BP wishes to be a wide-range resource and it's not devoted to any particular culture; still, it is clear that the Norse section, with the Snorra Edda and the selection of other Icelandic and Nordic works, is actually one of the most prominent in the website. Moreover, it will keep growing in the future, probably faster than other sections. Thus, BP is effectively becoming a landmark for those interested in the Scandinavian literature of the past, also because, as we explained before, it's usually difficult for the average Italian reader to find elsewhere good editions of Norse and Scandinavian texts. In this sense, we can actively contribute to the diffusion of the Nordic cultures, even if limited to its past history.

Dario Giansanti is a book seller in Viterbo, Italy. After having attended Natural Science studies, he has developed a special interest in anthropology, early-medieval languages and mythology. He is actually working with an Italian publishing house on a series of popular books about European myths and legends. Amidst these, a book about Scandinavian myths and legends will be published at the end of 2009. Stefano Mazza is a food industry researcher in Modena, Italy. He is attending a PhD programme in Food Biotechnology and is also an amateur philologist, with a particular interest in Old Norse and other Germanic languages. He has published research papers both in the life sciences and in literary criticism. In 2006 he joined $\mathrm{BP}$ and began the translation of Snorri Sturluson's Prose Edda. 